\title{
The Influences of Job Characteristics, Emotional Quotient, and Spiritual Quotient on Job Satisfaction and Nurses Performance At Islamic Hospital in Gresik
}

\author{
Kemal Farouq Mauladi \\ Faculty of Economic and Business, \\ 17 Agustus 1945 University, Surabaya, Indonesia \\ Ida Ayu Brahmasari \\ Faculty of Economic and Business, \\ 17 Agustus 1945 University, Surabaya, Indonesia \\ I. Dewa Ketut Raka Ardiana \\ Faculty of Economic and Business, \\ 17 Agustus 1945 University, Surabaya, Indonesia
}

\begin{abstract}
The research purpose was to analyze the influences of job characteristics, emotional quotient and spiritual quotient on job satisfaction and nurse performance at Islamic Hospitals in Gresik. The research approach using quantitative Research, population of this study is nurses in Three Islamic Hospitals in Gresik, with a total sample of 240 nurses. The data analysis technique uses Structural Equation Modeling (SEM). The results of this study indicate job characteristics influences performance, emotional quotient also influences job satisfaction and performance, while the spiritual quotient only influences job satisfaction, and effects of job characteristics on job satisfaction and spiritual quotient on performance are not significant. Finally, job satisfaction also influences performance.
\end{abstract}

Keywords: job characteristics, emotional quotient, spiritual quotient, job satisfaction, performance.

\section{INTRODUCTION}

Nursing conditions in Indonesia are quite behind compared to ASEAN countries such as Malaysia, Singapore and Thailand. The existence of Law No. 8 of 1999 concerning consumer protection increasingly demands that nurses carry out professional nursing practices become a necessity and an obligation that is not negotiable - bargaining again. Mastery of knowledge and skills, understanding of standard practice, standards of care and understanding of patient rights is an important thing for every person who practices nursing (Yanto, 2001).

The hospital as one of the health service facilities has a very strategic role in accelerating the improvement of the health status of the Indonesian people, one of the professions that have an important role in the hospital is nursing. Nursing is one of the hospital professions that plays an important role in carrying out efforts to maintain the quality of health services in hospitals. In the standard of evaluation and quality control, it is explained that nursing services guarantee the existence of high-quality nursing care by constantly involving themselves in quality control programs in hospitals (Didimus, 2013). 
In Gresik, there are now many Islamic hospitals with their respective advantages, and basically each hospital has the same goal, namely to fulfill patient satisfaction and provide the best service for their patients. With the many hospitals that are engaged in the field of health services have caused intense competition among the hospitals, because each hospital always strives to innovate in its efforts to improve the quality of its services to its patients in order to remain able to survive and grow according to their goals.

The number of Islamic hospitals in Gresik is 3 hospitals with a total of 595 nursing staff where each hospital has 100 to 250 nurses consisting of permanent employees and contract employees, from the number of hospitals and the number of nurses they can it was concluded that the hospital was one of the social service institutions that played an active role in the delivery of health services to the community. Islamic hospitals must be able to manage human resources, especially those who are in need of more attention because of their physical condition. Management of human resources is part of an organization where human resources can determine whether or not an organization is good.

Based on this background, the purpose of this study is to analyze: (1) the influence of job characteristics on job satisfaction, (2) the influence of job characteristics on performance, (3) the influence of emotional quotient on job satisfaction, (4) the influence of emotional quotient on performance, (5) the influence of spiritual quotient on job satisfaction, (6) the influence of spiritual quotient on performance, and (7) the influence of job satisfaction on performance.

\section{Job Characteristics}

\section{LITERATURE REVIEW}

Job characteristics are the nature of the task which includes responsibility, type of task and level of satisfaction obtained from the work itself. Jobs that intrinsically provide satisfaction and are more motivating for most people than unsatisfactory work (Stoner and Freeman, 1994).

Luthans (2006), the core model of the job characteristics conceptualized by Hackman and Oldham, is that certain job characteristics cause certain critical psychological states. In this case, the types of abilities, task identities, and the significance of the task lead to experiences of meaningful feelings; autonomy creates a feeling of responsibility; and feedback produces knowledge of the work results. When these three psychological conditions become more visible, employees feel more comfortable with themselves when they show good performance.

\section{Emotional Quotient}

Goleman (2006) "Emotional Quotient" argues that EQ is the ability to control negative things such as anger and doubt or a feeling of lack of confidence and also the ability to focus on positive things such as self-confidence and harmony with people around. Aspects of emotional quotient are:

1. Personal ability, namely the ability to manage yourself.

2. Social ability, namely the ability to handle a relationship.

3. Social skills, namely the ability to arouse responses desired by others.

\section{Spiritual Quotient}

Spiritual quotient according to Agustian, Ary Ginanjar (2003) "The Secret of Success Generating ESQ Power: An Inner Journey Through Al-Ihsan". Spiritual quotient is the ability to give meaning to worship for every behavior and activity, through steps and tauhidi (integrality) thinking and principled because of Allah. Spiritual quotient possessed by every 
human being to be able to provide meaning, values and goals in his life and increase motivation in work so that he is always excited because based on work is not compulsion but a worship.

Spiritually quotient individuals see this life as more grand and sacred, undergo as a vocation to do something unique, find ecstasy - the ecstasy of their lives from service to ideas that are not self-satisfaction, but to noble and great goals, which even often comes out of this world, is eternal and axiological. Life becomes more an instrument than an end. Ten criteria for measuring spiritual quotient are:

1. Self-intelligence.

2. Spontaneity, internally motivated.

3. See life from a vision and based on fundamental values.

4. Holistic, seeing the system and universality.

5. Affection (feeling of communicating, feeling of following the flow of life).

6. Respect diversity.

7. Adheres to the majority.

8. Basically questioning.

9. Rearrange in the big picture.

10. Firm in trouble.

\section{Job Satisfaction}

Spencer and Spencer (1993) cited by Wibowo (2007) state that job satisfaction is the basic foundation of people's characteristics and indicates how to behave or think, equate situations, and support for a long period of time. There are five types of job satisfaction, namely as follows:

1. Motive is something that people consistently think or want that causes action. Motives encourage, direct, and choose behavior towards certain actions or goals.

2. Properties are physical characteristics and responses that are consistent with the situation or information. The speed of reaction and sharpness of the eye is a physical characteristic of the competency of a combat pilot.

3. Self-concept is a person's attitude, values, or self-image. Confidence is people's belief that they can be effective in almost every situation is part of people's self-concept.

4. Knowledge is information that people have in a specific field. Knowledge is a complex competency.

5. Skills are the ability to do certain physical or mental tasks.

Bambang (2016) explains employee satisfaction is a measure of how far the company can meet the expectations of its employees related to various aspects of work and position. Job satisfaction is an emotional expression that is positive or pleasant as a result of an assessment of a job or work experience of someone.

\section{Employee Performance}

Prawirosentono (2002) argues that performance is the result of work that can be achieved by a person or group of people in an organization, in accordance with their respective authorities and responsibilities, in order to achieve the objectives of the organization in question legally and not according to morals ethics. This definition means that each individual must realize that the work he does must produce results. So work performance is defined as the results of work or the ability of work that is shown by someone, a group of people (organization) or a job at a certain time. The performance is in the form of end products (goods and services) or in the form of behaviors, skills, competencies, facilities and specific skills that support the achievement of goals, organizational goals. 


\section{METHODOLOGY}

This research includes the explanatory research, which is explains a relationship between exogenous variables to endogenous variables through intervening variables in testing hypotheses (Adianita Selfi A , Siti Mujanah, 2017). The population in this study were nurses at the Islamic Hospital in Gresik, which numbered 595 people. Based on the Slovin formula, a sample calculation of 240 nurses was produced, which in the data collection was carried out proportionally in three hospitals, namely Ibnu Shina Hospital, Islamic Hospital of Mabarrot NU Bungah, and Muhammadiyah Hospital.

Operational definitions are the operationalization of theoretical concepts which are derived into indicators that can be measured as follows:

1. Job characteristics. Luthans (2006), stated that work characteristics are internal (interpersonal) factors that move and influence behavior, measured by skill variety indicators, identical tasks, task significance, and feedback

2. Emotional quotient according to Tridhonanto (2009: 5) is measured by indicators of personal skills, social skills, and social skills.

3. Spiritual quotient is measured by using indicators of self-intelligence, spontaneity, seeing life from a vision and mission and based on fundamental values, holistic, compassion, respecting diversity, self-determination to carry out the majority, questioning fundamentally, rearranging in the big picture, firm in difficulty.

4. Job satisfaction is the level of pleasure someone feels for his role or work in the organization. The level of individual satisfaction that they receive is worth the various aspects of the work situation of the organization in which they work. Job satisfaction is measured by indicators of satisfaction with promotions, satisfaction with colleagues, and satisfaction with superiors.

5. Performance according to Rivai (2004) is measured by quality, quantity, timeliness, cost effectiveness, supervision needs, and individual relations.

Furthermore, the data analysis technique used in this study is Structural Equation Modeling (SEM) using the software of AMOS version 24.

\section{RESULT AND DISCUSSION}

The results of the descriptive analysis of job characteristics, emotional quotient, spiritual quotient, job satisfaction, and nurses performance at Islamic Hospitals in Gresik are all perceived to be high, this is indicated by the average score of the answers in the range of 3.4 4.2 (high), this shows that the average nurse at Islamic Hospital in Gresik has a good job characteristics, good emotional quotient, good spiritual quotient, good job satisfaction, and good performance.

The results of SEM analysis using AMOS v.24 are presented in Figure 1 below: 


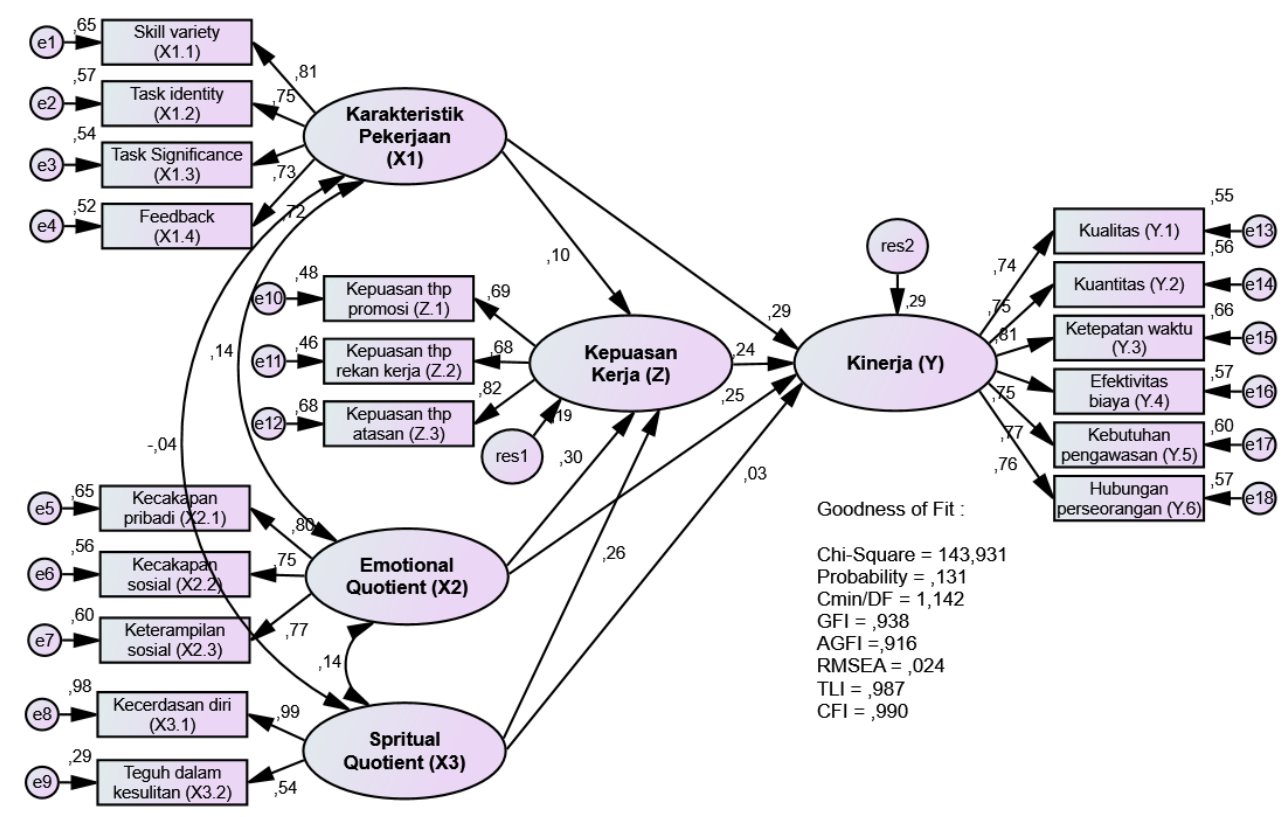

Figure 1. SEM Estimation Result

The goodness of fit test show that all goodness of fit criteria have provided an index that is in accordance with the recommended one. Thus, it was concluded that the model developed in this study was fit or matched with the facts in the field. Then it will be continued with hypothesis testing to find out the significance of the influence between variables. Furthermore, the results of hypothesis testing using standardized regression weight from structural models are:

Table 1. Hypothesis Testing Through Regression Weight

\begin{tabular}{|c|lrl|c|c|c|c|}
\hline Hip. & \multicolumn{3}{|c|}{ Path } & $\begin{array}{c}\text { Std. } \\
\text { Estimate }\end{array}$ & C.R. & $\begin{array}{c}P \\
\text { value }\end{array}$ & Note \\
\hline $\mathrm{H}_{1}$ & $\begin{array}{l}\text { Job Characteristics } \\
\left(\mathrm{X}_{1}\right)\end{array}$ & $\rightarrow$ & $\begin{array}{l}\text { Job Satisfaction } \\
(\mathrm{Z})\end{array}$ & 0,098 & 1,303 & 0,193 & $\begin{array}{c}\text { Not } \\
\text { significant }\end{array}$ \\
\hline $\mathrm{H}_{2}$ & $\begin{array}{l}\text { Job Characteristics } \\
\left(\mathrm{X}_{1}\right)\end{array}$ & $\rightarrow$ & Performance $(\mathrm{Y})$ & 0,293 & 4,139 & 0,000 & Significant \\
\hline $\mathrm{H}_{3}$ & $\begin{array}{l}\text { Emotional Quotient } \\
\left(\mathrm{X}_{2}\right)\end{array}$ & $\rightarrow$ & $\begin{array}{l}\text { Job Satisfaction } \\
(\mathrm{Z})\end{array}$ & 0,297 & 3,563 & 0,000 & Significant \\
\hline $\mathrm{H}_{4}$ & $\begin{array}{l}\text { Emotional Quotient } \\
\left(\mathrm{X}_{2}\right)\end{array}$ & $\rightarrow$ & Performance $(\mathrm{Y})$ & 0,254 & 3,311 & 0,000 & Significant \\
\hline $\mathrm{H}_{5}$ & $\begin{array}{l}\text { Spiritual Quotient } \\
\left(\mathrm{X}_{3}\right)\end{array}$ & $\rightarrow$ & $\begin{array}{l}\text { Job Satisfaction } \\
(\mathrm{Z})\end{array}$ & 0,258 & 3,307 & 0,000 & Significant \\
\hline $\mathrm{H}_{6}$ & $\begin{array}{l}\text { Spiritual Quotient } \\
\left(\mathrm{X}_{3}\right)\end{array}$ & $\rightarrow$ & Performance $(\mathrm{Y})$ & 0,027 & 0,417 & 0,677 & $\begin{array}{c}\text { Not } \\
\text { significant }\end{array}$ \\
\hline $\mathrm{H}_{7}$ & Job Satisfaction $(\mathrm{Z})$ & $\rightarrow$ & Performance $(\mathrm{Y})$ & 0,240 & 2,966 & 0,003 & Significant \\
\hline
\end{tabular}

Parameter estimation results show there are five hypotheses accepted, namely the influence of job characteristics on performance, the effect of emotional quotient on job satisfaction and performance, the influence of spiritual quotient on job satisfaction, and the influence of job satisfaction on performance, while two hypothesis are the job characteristics on job satisfaction and the influence of spiritual quotient on performance are known to be not significant (hypotheses rejected). 
The percentage of the effect of job characteristics, emotional quotient, and spiritual quotient on job satisfaction is $19.1 \%$, while the percentage effect of job characteristics, emotional quotient, spiritual quotient, and job satisfaction on performance is $29.5 \%$.

\section{CONCLUSION}

Based on the results of the research and discussion that has been described, it can be concluded: (1) job characteristics has on effect on job satisfaction, (2) job characteristics influences performance, (3) emotional quotient influences job satisfaction, (4) emotional quotient influences performance, (5) spiritual quotient influences job satisfaction, (6) spiritual quotient has no effect on performance, and (7) job satisfaction influences performance.

\section{References}

Adianita Selfi A , Siti Mujanah, Candraningrat. 2017, Kompetensi Karyawan, Emotional Quotient dan Self Efficacy pengaruhnya Terhadap Organizational Citizenship Behavior dan Kinerja Karyawan Pada Indomobil Grup di Surabaya, Journal of Research in Economics and Management Vol.17(1):12-15

Bambang, Ika 2016 “Pengaruh Kepuasan Kerja Dan Komitmen Organisasional Terhadap Kinerja Karyawan” Jurnal Administrasi Bisnis Vol 34 No 1

Didimus, 2013.p.35.Konsep dan penerapan metodologi penelitian ilmu keperawatan. Jakarta: Salemba Medika Goleman 2006 "Kepemimpinan Berdasarkan Kecerdasan Emosi PT Gramedia Putaka Utama, Bandung”. Jurnal Akutansi Vol 4, No 1

Luthans, Fred. 2006. "Organizational Behavior", 10 th Edition, Alih Bahasa Vivi Andika Yuwono dkk, Andi, Yogyakarta Nandha Meta K.D, 2015.

Spencer, L \& Signe M. Spencer, 1993. Competence at Work, Models For Superior Performance. John Wiley \& Sons, Inc. Canada

Stoner J.A.F, R.E. Freeman, 1994. Manajemen, Edisi 5, Penerbit Intermedia, Jakarta

Tridhonanto. Melejitkan Kecerdasan Emosi (EQ). Edisi 1, Penerbit PT. Elex Media Komputindo, Jakarta.

Wibowo, 2007 “Komitmen Organisasional terhadap Kinerja Karyawan” Edisi ke tiga. Jakarta. Rajawali Pers.

Yanto. 2001.p.12. Hubungan Antara Burnout Dengan Self Eficacy Pada Perawat Di Ruang Rawat Inap Rsud Prof . Dr Margono Soekarjo Purwokerto. Jurnal Keperawatan Soedirman Volume 2 No 3

Zohar D. dan Marshall, S. 2001. SQ, Memanfaatkan Kecerdasan Spiritual Dalam Berpikir Integralistik dan Holistik untuk Memaknai Kehidupan. Edisi 1, Penerbit Mizan, Bandung. 